KAZIMIERZ KRZAKIEWICZ SZYMON CYFERT

\title{
Potential for imitation as \\ a dynamic capability of organisation'
}

Prof. Kazimierz Krzakiewicz Poznań University of Economics

Prof. Szymon Cyfert Poznań University of Economics

\section{Introduction}

There is agreement in current writing that dynamic capabilities are useful as a theoretical construct in researching competitive advantages of firms in today's changed business environment, and that these capabilities differ from the typical "operational" ones in that their emphasis is on change management (Eisenhardt, Martin 2000, Teece 2007; Teece 2012).

Until recently, what was treated as unique resources in strategic management were financial, human and other resources, and their uniqueness was examined mostly in quantitative terms. However, globalisation of economic processes has meant that a degree to which resources are unique determine their quality, as a result of which they cannot be evaluated solely in quantitative terms. Such unique resources include competencies, dynamic capabilities and other intellectual resources within organisations, including their potential for innovation and imitation. The purpose of this article is to discuss the

1 The project was financed by the National Center for Science awarded on the basis of the decision number DEC-2013/11/B/HS4/00697. 
construct of potential for imitation considered in terms of the dynamic capability of organisation.

\section{Dynamic capabilities of organisation}

The first comprehensive analysis of the concept of dynamic capabilities was offered by Teece, Pisano and Shuen (1990), who observed that rather than being a mere set of essential organisational resources, an enterprise also includes certain mechanisms for developing and utilising new routines and capabilities which underlie effective management. The concept of dynamic capabilities was further developed by D.J. Teece, G. Pisano and A. Shuen in 1997. They argued that treating a business firm as a collection of resources fails to explain fully why some highly performing organisations are both very nimble in their response to change and capable of coordinating their internal and external knowledge resources effectively (Teece, Pisano 1997). D.J. Teece, G. Pisano and A. Shuen made clear the importance of analysing the shifting character of the environment and, in effect, of the key role of strategic management in adapting, integrating, and reconfiguring internal and external organisational behaviours, resources, and functional competences toward changing environment. Described dynamic capabilities of firms as their capacity to integrate, create and constantly transform internal and external knowledge resources and utilise those resources in rapidly changing environments. In their view, in order to sustain their competitive advantage, firms should acquire and shed their resources to the extent that reflects the changes in their environment. Such processes are well served by dynamic capabilities.

The discussion started by D.J. Teece, G. Pisano and A. Shuen launched a broad process of reflection in management science, encouraging numerous scholars to offer their own original definitions of dynamic capabilities. Whatever their specific research optics, however, what these definitions have in common is the belief that, broadly speaking, dynamic capabilities are those organisational processes that seek to reconfigure the firm's resources. Some have also argued that organisations develop their dynamic capabilities internally, rather than obtaining them from the market (Zollo, Winter 2002), pointing out the clear relationship between the firm's dynamic capabilities and its competitive advantage (Teece et al., 1997). Griffith and Harvey (2001), in turn, argue that "global" dynamic capabilities involve the creation of "difficult-to-imitate" combinations of resources which may provide a sustainable competitive advantage to a firm. H. Lee at al. (2002), too, take a similar view, emphasising

Potential for imitation as a dynamic capability of organisation 
the importance of dynamic capabilities as a source of competitive advantage in rapidly changing environments. While other scholars, too, associate dynamic capabilities with competitive advantage, they argue that the relationship is indirect. For example, C. Zott (2003) notes that dynamic capabilities are indirectly linked with sustainable firm performance. C.E. Helfat (1997), on the other hand, separates dynamic capabilities from the firm's direct activities and takes the view that dynamic capabilities do not necessarily lead to competitive advantage. Helfat argues that over the period in which dynamic capabilities can transform a resource, the renewal is not necessarily valuable and will not lead to developing what are so-called VRIN (valuable, rare, imperfectly imitable and non-substitutable) resources. As such, dynamic capabilities may have a disadvantageous effect or their impact on competitive advantage may be short-lived.

The value of dynamic capabilities is yet another important point of analysis, because their impact may only be assessed in hindsight. M. Zollo and S.G. Winter (2002) argue that maintaining and supporting dynamic capabilities requires significant expenditure on cognitive, organisational and operating processes and a substantial investment of time and energy on the part of managers. $M$. Zollo and S.G. Winter also make a point that if managers are wrong in their assessment of their firm's situation, they will contribute to developing dynamic capabilities that are inadequate for that situation. Utilising and developing such capabilities will have negative consequences.

\section{Potential for imitation in dynamic capabilities}

Chandler demonstrated that, by always using the same strategy and the same competences, organisations, particularly those that succeed against their competitors, might fall into the trap of their own success and stagnate. The only way out of this trap is to develop dynamic capabilities that will provide longterm competitive advantage. One of such capabilities is the ability to imitate, conceptually described as the potential for imitation (Kale, Little 2007; Kim, 1997).

An imitation strategy is about improving existing solutions inline with whatever a specific market domain expects. By tapping into its potential for imitation, an organisation avoids considerable R\&D expenditure: a product it tries to copy has already been developed, leading to significantly reduced overheads and higher margins. The focus in building the potential for imitation is on mastering new technologies, improvements to existing solutions, and launching production or 
services. A creative imitator does not come up with a new product or service, but improves the existing one and offers it on the right market. For imitators, therefore, a product's added value, which helps them become a market leader, is created primarily through their organisational capabilities rather than the technical ones. P. Drucker confirms this when he says that an imitation strategy starts with the market and not production activities.

A creative imitation strategy is market-oriented and follows the rules of the marketplace, its effectiveness depending on strong market growth dynamics. Imitators are successful because they win over customers from original creators because they have a better understanding of what those customers need. As such, an imitation strategy meets the existing demand rather than creating one that was not there. That said, it is not free from significant risk which may result from misreading the market and launching copycat products without good market prospects.

An imitation strategy is one whereby organisations take existing market innovations (in products, technologies, management, etc.) and make some limited enhancements and improvements to them. The key distinguishing features of imitators should be a proper organisational culture, technological and production capabilities, a good insight into customers' expectations, and a relatively strong market position. Copycat activities may involve innovations originating from and produced by both large and small innovative businesses. Quite often, too imitator companies become leaders in their sectors and overtake market pioneers.

In an imitation strategy, an imitator "bets" on the effectiveness of its competitors' innovations, and works to improve them. This kind of strategy is effective in practice provided that the imitator has appropriate production capacity and resources (especially intellectual capital and financial wherewithal). This allows the imitator to achieve a proper production scale for its copycat products and place those products on the markets the innovator has not yet ventured into.

Organisations which choose imitation as their strategy spend less on R\&D, which significantly reduces their business risks. At the same time, this might result in a diminished likelihood of their financial success. Paradoxically, lacking expertise, the imitator incur higher production or service delivery costs. Imitators might also have smaller market shares and, especially early on, their customers might not trust them to deliver high-quality products they have learnt to expect from the brands of pioneering innovators with appropriate know-how. For this reason, copycat products are usually offered in developing countries, especially at first. 
An imitation strategy also often involves aggressive marketing policy techniques to help the imitator strengthen its position in the targeted market segment.

\section{Imitating innovation}

P. Kotler postulates that the problem of competitiveness and market share retention can be solved by continuous innovation whereby new products and services are developed all the time. However, even market leaders are unable to use the strategy at all times, not to mention small organisations without adequate R\&D capability. For them, product imitation takes centre stage as a strategy that is often more effective than an innovation strategy. Even though imitation is commonly regarded as a "less worthy" choice, sometimes even unlawful, in practical terms it is a strategy that brings good economic performance and secures competitive advantage. Its effectiveness lies in the fact that the imitator has to pay significantly less than the innovator in terms of the costs involved obtaining necessary information, product development, testing and marketing, customer publicity, etc. At the same time, imitation tends to win against innovation where:

- there is high technological uncertainty and relatively low barriers to entry,

- there is a low level of intellectual property protection,

- markets are in a growth stage,

- the product has a short lifecycle,

- product prices are vulnerable to economies of scale,

- imitation helps to distribute the product widely and ensure its greater availability compared to the original product.

A study by H. Mansfield (in: Shenkar, 2012) on 48 innovative products found that most of them were copied within four years; that, on the average, the imitation cost was about $65-75 \%$ of the original cost; and that the imitation R\&D and launch time was $70 \%$ of that for the original product. H. Mansfield's later study of 100 firms found that in some cases organisations decided to launch their imitation within 12 to 18 months (compared to 10-15 years on average to launch the innovation). Mansfield also showed that patents were no major obstacle to imitation (Shenkar, 2012). The relatively high costs are because the imitator has to go through a number of the same steps as the innovator with respect to research, product technological development, investment in equipment, prototype construction, product manufacturing and marketing activities. 
An imitation strategy gives some businesses a chance to continue on the market and build a sustainable competitive advantage from scratch. At the same time, strategic flexibility requires firms to respond to their competitors' market and innovative activities.

T. Levitt (2006) writes that, as recently as 50 years ago, even well-managed firms with sound strategic planning handed imitation in a rather chaotic and random manner. This has not changed much to this day. A vast majority of businesses have no imitation strategy, which limits their approach to what imitation can potentially bring to legal protection of their intellectual property. This constrains their ability to observe, evaluate and respond to changes in their environment, and limits their strategic leeway.

On analysis, developments in the Polish economy reveal inadequate pressure on innovation. Most technologies or products used here are modelled on Western designs, a result of innovation spending that is a number of times (...) lower than in the developed countries. A substantial number of technologies used by Polish firms are copies of Western technologies.

Importantly, copying Western designs, a process frequently resorted to, not always brings its desired results. Management practice shows that a strategy of chasing market leaders should have different strategic objectives for different periods. New technologies cannot be developed until after the relevant expertise and skills have been mastered.

Usually, innovative products which are new on the market come with certain limitations and it is only in rare cases that innovators can do everything the way it should be (Maksimov, Sun, Luo, Wang, 2014). This is because, usually, there is no predicting how the product will be received by the market. That may be good news to imitators who can base their product development on feedback received from consumers, offering a product that will surpass the original.

Importantly, too, there are cases where companies offering improved imitations happen to find new market domains and customer segments, which helps them establish a strong market position and become a market pioneer. This is illustrated by Chinese retailer Alibaba whose owner, J. Ma, was so fascinated by the U.S. technology, that he decided to go beyond copying its ideas and came up with his own original business idea. His online service was designed to help small and medium Chinese firms find customers. J. Ma's entry into a new domain, that of offering a retail platform to sellers, made him the richest Chinese and the $18^{\text {th }}$ richest man in the world. Innovators' products are rarely copied in full. Copycat technologies, designs or functions are often reworked and improved upon and imitators pick only those parts of innovators' offering that suit their own purposes.

Potential for imitation as a dynamic capability of organisation 
There are numerous examples of successfully executed strategies to improve products and services based on competitors' creations. For example, S\&S Cycle brought significant improvements to Harley-Davidson engines and their product is equally popular as Harley's. McDonald 's business idea, in turn, was based on White Castle's. Visa and MasterCard became successful by imitating a less popular Diners Club. Apple's Macintosh is merely an improved version of Xerox's product. Companies which are seen as leaders today were not innovators in their respective sectors. What they did was to master dynamic capabilities involved in copying pioneers' ideas, which they then effectively modified. Some of them did not stop at successfully copying one idea only and have made imitation part and parcel of their business. For example, Apple's ability to integrate imitation and innovation is an important source of its success. Even though Apple is treated as an innovator, its key dynamic capability is actually in integrating its ideas with other firms' technologies. Obviously, when it adopts ideas from others, Apple gives them its own stamp - that is to say, it does not just copy those ideas, but adds to and improves on them.

Another example is Procter \& Gamble, a recognised technological leader, which did a strategic U-turn from innovation to imovation, reducing its R\&D spending and taking over about $50 \%$ of ideas and concepts from other firms. Therefore, unlike in the traditional approach to imitation where the goal is fully to recreate the product and business situation, imitation and innovation are integrated on the assumption that imitation can be useful in developing future innovations or formulating new market leadership strategies.

\section{Conclusion}

With ever shorter product lifecycles and more and more new products being offered, the go-to strategy is increasingly "imovation" which combines innovation and imitation (). Imovation as a strategy goes beyond merely copying competitors' products and involves imitation of a selection of relevant product features. The art of imovation is to find a proper balance between innovation and imitation that will result in competitive advantage and increased productivity while reducing costs. Imovators use imitation as a starting point to develop and improve new products and services, and to tap into the yet untapped market potential.

\section{Summary}

Potential for imitation as a dynamic capability of organisation

Until recently, what was treated as unique resources in strategic 
management were financial, human and other resources, and their uniqueness was examined mostly in quantitative terms. However, globalisation of economic processes has meant that a degree to which resources are unique determine their quality, as a result of which they cannot be evaluated solely in quantitative terms. Such unique resources include competencies, dynamic capabilities and other intellectual resources within organisations, including their potential for innovation and imitation.

The purpose of this article is to discuss the construct of potential for imitation considered in terms of the dynamic capability of organisation. The starting point in the study was to outline the essence of the dynamic capabilities of the organization, then the potential of imitation in the dynamic capacity system was embedded in order to finally refer to the link between innovation and imitation.

Key words: Dynamic capabilities, imitation, imitation potential, innovations.

\section{Streszczenie}

\section{Potencjał imitacji jako dynamiczna zdolność organizacji}

Do niedawna w zarządzaniu strategicznym jako unikalne zasoby traktowano zasoby finansowe, ludzkie czy wiedzę. Unikalność traktowano przy tym przede wszystkim w kategoriach ilościowych. Jednakże globalizacja procesów gospodarowania spowodowała, że zakres unikalności determinuje jakość zasobów, przez co zasoby nie mogą być analizowane wyłącznie w kategoriach ilościowych. Do takich unikalnych zasobów można przede wszystkim zaliczyć kompetencje, dynamiczne zdolności i inne intelektualne zasoby organizacji, w tym innowacyjny i imitacyjny potencjał organizacji.

W opracowaniu przeprowadzono dyskusję nad konstruktem potencjału imitacji rozpatrywanym w kategoriach dynamicznej zdolności organizacji. Punktem wyjścia w opracowaniu uczyniono zarysowanie istoty dynamicznych zdolności organizacji, w dalszej części osadzono potencjał imitacji w systemie dynamicznych zdolności, po to by w zakończeniu odnieść się do powiązania innowacji i imitacji. 


\section{Słowa}

kluczowe: Dynamiczne zdolności, imitacja, potencjał imitacji, innowacje.

\section{JEL}

\section{Classification: $\mathrm{O} 310$}

\section{References}

1. Eisenhardt K., Martin J. (2000), Dynamic capabilities: what are they? Strategic Management Journal, 21(10-11), pp. 1105-1121.

2. Griffith D.A., Harvey M.G. (2001), A Resource Perspective of Global Dynamic Capabilities, Journal of International Business Studies, Vol. 32, No. 3, pp. 597-606.

3. Helfat C.E. (1997), Know - how and asset complementarity and dynamic capability accumulation: the case of $R \mathcal{E} D$, Strategic Management Journal, 18(5), pp. 339-360.

4. Kale D., \& Little S. (2007), From imitation to innovation: The evolution of $R \mathcal{E} D$ capabilities and learning pro cesses in the Indian pharmaceutical industry, Technology Analysis \& Strategic Management, 19 (5), p. 589-609.

5. Kim L. (1997), Imitation to innovation: The dynamics of Korea's technological learning, Boston, Harvard Business School Press.

6. Lee H., Smith K., Grimm C.M., Schomburg A. (2002), Timing order and durability of new product advantages with imitation, Strategic Management Journal, 21, pp. 23-31.

7. Levitt T. (2006), What Business Are You In?, Harvard Business Review, October.

8. Maksimov V., Sun J., Luo Y., Wang S.L. (2014), From imitation to imutation: conditions and consequences, Academy of Management, Philadelphia.

9. Shenkar O. (2012), Just imitate it! A copycat path to strategic agility, Ivey Business Journal, 76 (3), pp. 1-5.

10.Teece D.J., Pisano G., Shuen A. (1997), Dynamic capabilities and strategic management, Strategic Management Journal, 18 (7), pp. 509-533.

11.Teece D.J., Pisano G., Shuen A. (1990), Firm capabilities, resources, and the concept of strategy, CCC Working Paper 90-8, Center for Research on Management, University of California, Berkeley.

12. Teece D. J. (2007), Explicating dynamic capabilities: The nature and microfoundations of (sustainable) enterprise performance. Strategic Management Journal, 28 (13), pp. 1319-1350.

13. Teece D.J. (2012), Dynamic Capabilities: Routines versus Entrepreneurial Action, Journal of Management Studies, 49(8), pp. 1395-1401.

14. Winter S.G. (2003), Understanding dynamic capabilities, Strategic Management Journal, 24 (10) pp. 991-995. 


\section{Management}

2018

Vol. 22, No. 1

15. Zollo M., Winter S.G. (2002), Deliberate learning and the evolution of dynamic capabilities, Organization Science, 13 (3), pp. 339-351.

16. Zott C. (2003), Dynamic capabilities and the emergence of intra-industry differential firm performance: Insights from a simulation study, Strategic Management Journal, Vol. 24, No. 1, pp. 97-125.

Potential for imitation as a dynamic capability of organisation 